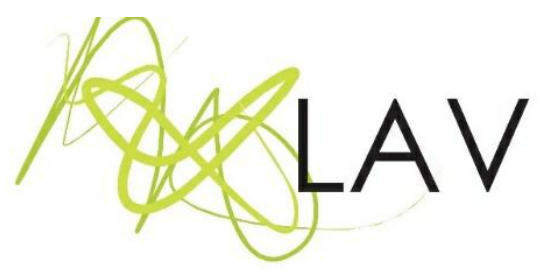

\title{
SÓ AS ARTES NOS SALVAM!!!!! \\ - as tantas crianças que há em nós -
}

\author{
ONLY THE ARTS SAVE US!!!!! \\ - the many infants that there are in us -
}

Nilda Guimarães Alvesi Universidade do Estado do Rio de Janeiro

Júlia da Silva Limaii Universidade do Estado do Rio de Janeiro

Rafaela Rodrigues Conceiçãoiii Universidade do Estado do Rio de Janeiro

Talita Malheiros Gregorioiv Universidade do Estado do Rio de Janeiro

\begin{abstract}
Resumo
O presente artigo resulta dos estudos com os cotidianos, como 'espaçostempos' possíveis para encontros diversos com as artes, possibilitando narrativas, afetos e criações a partir das muitas redes educativas que formamos e que nos formam. As redes de 'práticasteorias' da criação e uso das artes nos faz compreender os tantos 'dentrofora' das escolas, nos ajudando a perceber os modos como são criados os 'conhecimentossignificações' necessários ao viver cotidiano, seja neste período pandêmico ou não, nas escolas reais ou virtuais. As memórias em contato com o cinema nos trazem a compreensão dessas infâncias tão diferentes produzidas no mundo. Ao entendermos as 'cineconversas' como metodologia e lócus central dos processos de pesquisa em nosso grupo, objetivamos pensar as múltiplas memórias-narrativas produzidas ao 'verouvirsentirpensar' o processo dialógico com os filmes como provocadores de sentimentos e sensações e possibilidade de estar perto dos 'fazeressaberes' e narrativas de todos os 'praticantespensantes' das pesquisas.
\end{abstract}

Palavras-chave: artes; imagens; sons; 'cineconversas'; infâncias.

Enviado em: 30/04/21 - Aprovado em: 09/06/21

\begin{abstract}
The present article results from studies with daily life as possible 'space-times' for diverse encounters with the arts, enabling narratives, affections and creations from the many educational networks that we form and that form us. The networks of 'practical-theories' of the creation and use of the arts make us understand the many 'inside-outside' of schools, helping us to understand the ways in which the necessary 'knowledge-meanings' are created in everyday life, whether in this pandemic period or not, in real or virtual schools. Memories in contact with the cinema bring us an understanding of the very different childhoods produced in the world. When we understand the 'cineconversations' as a methodology and central locus of the research processes in our group, we aim to think
\end{abstract}


about the multiple narrative memories produced by 'see-hear-feel-think' with the films as provoking feelings and sensations and the possibility of being close to the 'do-know' and narratives of all 'thinking practitioners' of the research.

Keywords: arts; images; sounds; 'cineconversations'; childhood.

\section{Pandemias}

Em casa desde março de 2020, contabilizando as pouquíssimas saídas (4?5?...15? Para a mais jovem entre nós), perguntamos, buscando ativar nossas memórias: o que fizemos? Olhamos pelas janelas, ouvíamos os sons que vinham de fora - nos arrepiando com a concentração de gente (homens, mulheres e crianças) nos bares e nas esquinas, em especial em dia de jogos. Buscamos sem parar a Internet, em redes de contatos, teclando no Google... buscando respirar melhor, apesar dos nossos medos.

Como membro de uma família, precisamos reorganizar: os 'espaçostempos' ${ }^{1} \mathrm{da}$ casa; o uso em horários que muitas vezes coincidem, de um único artefato tecnológico de comunicação; as tarefas de limpeza do que vem de fora da casa e das "bagunças" de crianças e jovens; etc. Como profissional, após anos de proibição, pelas autoridades educacionais, de uso e criação com artefatos tecnológicos, como o celular e outros, tivemos que entrar "da noite para o dia" nesses meios interditados e conduzir processos pedagógicos com os estudantes de todos os níveis, percebendo, com intensidade, um dos maiores aspectos da exclusão social no Brasil: a enorme quantidade de estudantes que estavam fora desse tipo de contato por não possuírem Internet boa, não possuírem esses artefatos ou os ter com pouquíssima possibilidade de uso. Nesse momento, então, os contatos por som - que gastam muito menos que as imagens - começaram a se fazer presentes.

Assim, em todas essas atividades, fomos melhor sentindo os sons, que nos acompanham sem parar e que, nesse afastamento compulsório, nos traz às vidas dos outros para as nossas vidas. Por necessidade de continuidade da pesquisa e exigências de distanciamento social, transformando encontros presenciais em encontros online, 'vendoouvindosentindopensando' filmes², muitos filmes, com seus enredos, imagens, sons

\footnotetext{
${ }^{1}$ Com esses termos assim grafados, juntos, em itálico e entre aspas simples, vistos no campo das ciências como dicotomizados, desde a Modernidade, buscamos mostrar que eles têm significado limites às pesquisas com os cotidianos, nas quais desenvolvemos nosso trabalho em pesquisa, extensão e docência.

2 Nas pesquisas que desenvolvemos, na qual usamos muitos filmes, inicialmente, chamávamos os encontros que fazíamos para o desenvolvimento do processo de pesquisa, de 'cineclubes'. Com o tempo, fomos percebendo que esse nome era impróprio, já que os 'cineclubes' têm uma história e um processo na qual os filmes ocupam o lugar central do trabalho. Conosco, esse lugar era ocupado pelas conversas entre os participantes ('praticantespensantes') da pesquisa e os filmes entravam para, a partir de expressões artísticas, com suas criações, pudéssemos fazer nossas conversas muito mais abertas, para mais e melhor pensar os processos
} 
e suas belezas, tristezas, esperanças... antes dos encontros para fazer nossas 'cineconversas' e pensar escolas reais e virtuais.

Neles, os sons ganham muito mais sentido, porque fomos nos preparando para isso. Também fomos ampliando nossas vivências com eles: mexendo mais o corpo; ouvindo podcasts - o que criamos no grupo a que demos o título "Cotidianos e Currículos" e muitos outros; nos dando mais tempo para ouvir músicas...

Poder dançar, sozinha ou com alguém 'nosso' - neta, filho, marido, irmã - nos fez pensar que, apesar das muitas coisas horríveis que estavam trazendo essa pandemia (nesse governo genocida), estávamos tendo a possibilidade de relembrar e criar memórias: de como dançávamos com nossos avós, pais, tias, amigos...em nossas tantas infâncias. E como podíamos entender essas danças atuais como um reencontro com essas infâncias.

Cada um no seu quadrado - seria melhor dizer retângulo? - Observando os chãos preenchidos e vazios - ora com objetos ora com afetos, nos conectamos entre lives, ecos, ruídos e silêncios, em correrias de uma aula a outra, com as alegrias nas bagunças com as crianças, entre uma foto e outra, um post e outro, um compartilhamento e outro, uma conversa e outra nas tantas plataformas, e as memórias que vinham de nossas tantas vivências. Com membros da família ou sozinhas, remexemos em caixas e álbuns buscando fotografias nossas de "antes".

Em algo que nomeamos como lar, experimentamos as diferentes formas de 'fazersentir' nesses 'espaçostempos', seguindo o surgir e o finalizar de diferentes vozes, sons e conversas que caminham nos tantos afetos e emoções, ziguezagueando junto 'nosdoscom' os cotidianos. Entre e nos cantos, observamos detalhes que antes não víamos, nos sensibilizamos com acolhidas e metamorfoses da partilha de sensibilidade que esbarrou ao mesmo tempo em algo comum a todos, enquanto virava 'espaçotempo' de disputas por um comum.

Com tudo isso, experienciando com maior intensidade, o que já sabíamos: a partilha do sensível se movimenta pela necessidade das artes, que nos trazem possibilidades de relações mais humanas, agudizando nossos sentidos de comunidades: familiar, com as fotografias e as narrativas de histórias de "antes"; escolar, com buscas coletivas nas dificuldades de manipular artefatos que ignoramos, que nos foram trazendo, músicas e mostras de artes visuais, permitindo experiências éticas, estéticas e políticas.

curriculares nas escolas. O nome 'cineconversas' foi proposto por Rosa Helena Mendonça, bolsista PNPD/CAPES/UERJ, à época no grupo, e saudada e usada a partir de então pelos membros do grupo de pesquisa. 


\section{As redes educativas que formamos e que nos formam}

Trabalhando há muito com a ideia de 'redes educativas', que formamos e nas quais somos formados para compreender as ações humanas cotidianas e suas formas de criar e usar 'conhecimentossignificações'. No presente, nós as nomeamos assim:

das 'práticasteorias' da formação acadêmico-escolar; das 'práticasteorias' pedagógicas cotidianas; a das 'práticasteorias' de criação e "uso" das artes; das 'práticasteorias' das políticas de governo; das 'práticasteorias' coletivas dos movimentos sociais; das 'práticasteorias' das pesquisas em educação; das 'práticasteorias' de produção e 'usos' de mídias; das 'práticasteorias' de vivências nas cidades, no campo e à beira das estradas (ALVES, 2019, p.115).

Todas estas redes são entendidas como de 'práticasteorias', pois percebemos que nelas são criadas, permanentemente, práticas necessárias e possíveis ao viver cotidiano e intimamente relacionadas à criação de formas de pensamento a que podemos chamar 'teorias'.

Neste artigo, pretendemos dar destaque às redes de 'práticasteorias' da criação e uso das artes. Com essas redes, vamos percebendo e compreendendo melhor os 'espaçostempos' em que vivemos e os tantos 'dentrofora' das escolas, em nossas ações profissionais, o que nos ajuda a perceber os modos como são criados 'conhecimentossignificações' necessários ao viver cotidiano.

Em função disso, até estarmos em um grupo de pesquisa em que as conversas se desenvolviam, não tínhamos esse olhar para os cotidianos, nem mesmo paramos para pensar na tessitura das redes educativas em nossas vidas. Uma de nós, por exemplo, no ano do golpe da ex-presidente Dilma Rousseff, quando estava no primeiro ano da Escola Média, desenvolveu um debate, orientado por uma professora de História, em torno da tensão formada na época em volta disso - "golpe ou impeachment?".

Desde já, esta autora deste texto se via do lado justo da história, acredito que esse segmento de consciência não se deu a partir desse momento, mas sim, de sua existência enquanto corpo político - mulher, negra, periférica. Mas, olhando para antes, esse debate com os 'conhecimentossignficações' que trouxe foi esclarecedor, marcante, por sua dinâmica 'inovadora' para os estudantes, entendendo-os como 'praticantespensantes' daquela situação, com direito à voz e à expressão de suas ideias. Essa ação foi lembrada aqui pelo tanto de lúdico que essas atividades curriculares possuem, nos fazendo pensar que ali, também estamos brincando para pensar.

Nessas redes educativas com que trabalhamos, então, vão se destacando, em inúmeros momentos aquelas de criação e 'uso' das artes: nossas ações no grupo, seja nos 
encontros de pesquisa/extensão, seja em aulas - hoje todas na Internet, através de meets variados - ao se darem sempre com filmes nos trazem sempre essa sensação de 'brincadeiras', de forma a despertar em nós o virtual, as formas de ser criança, sempre. Ao 'verouvirsentirpensar' ${ }^{3}$, em cada filme trazido às 'cineconversas ${ }^{4}$, com suas tantas possibilidades de compreender uma obra e as realidades que cria, sentimo-nos, muitas vezes, crianças: descobrindo um novo filme; rindo de algumas coisas que traziam; fugindo de coisas terríveis que apresentava, não querendo ver aquilo... Conseguindo perceber, assim, as tantas relações entre as redes educativas e as diferentes relações entre os que nelas estão incluídos ou excluídos.

\section{Memória-narrativas de uma estudante de Letras}

"Existe uma Força Criativa Universal conectando todos os seres e coisas, uma fonte de amor e sabedoria que pode ser extraída e revelada através da criação de obras de arte". Em função dessa citação de Ervin Laszlo, trago o relato de algumas experiências marcantes com a arte no decorrer da minha vida. Ainda no ensino fundamental, na escola em que estudava, eram realizados 'passeios teatrais' - ida a um espetáculo para crianças em teatros. Quando um deles era feito, era um acontecimento! Já era de se esperar, uma atividade fora do ambiente escolar que colocava crianças com 6, 7, 8 anos em contato com o mundo, com arte e outras crianças... Era uma euforia do começo ao fim! Pelo que lembro, o teatro que íamos era na Gávea e havia um rapaz caracterizado de mágico que nos acompanhava desde a nossa partida da escola até a despedida para voltarmos para casa, ele conversava, animava e ensinava algumas canções das peças, uma lembrada por mim até hoje: alecrim, alecrim dourado / que nasceu no campo / sem ser semeado / Foi meu amor / Que me disse assim / Que a flor do campo é o alecrim.

Mais tarde, aos 15 anos, mantinha uma amizade bem próxima com as amigas de minha irmã e frequentemente fazíamos chamadas de vídeo e uma das meninas tocava instrumentos musicais - violão, guitarra, teclado - e sempre que surgia o assunto, eu pedia para que ela desse 'uma palinha' e, em toda ligação, isso se repetia. Foi a partir disso que surgiu meu interesse pelo violão.

Com isso, fiz um pedido de presente de aniversário à minha querida tia e ela prontamente atendeu: recebi um violão e... explodi de felicidade! Fomos atrás de um

\footnotetext{
${ }^{3}$ Nas pesquisas desenvolvidas no grupo de pesquisa e extensão fomos percebendo que ao assistirmos um filme muito se passa em nós, ao mesmo tempo. Por isso indicamos isso escrevendo assim 'verouvrisentirpensar'.

${ }^{4}$ Durante um tempo, usamos 'cineclube'. Com o desenvolvimento das pesquisas, fomos percebendo que o que realizávamos eram 'cineconversas' com o filme - obra de arte - nos abrindo a brincadeiras, belezas, questões sociais, possibilidades de ações curriculares outras etc.
} 
professor. Como minha tia frequenta a igreja católica do bairro, ela se pôs a falar com um dos músicos que tocava na missa. O rapaz disse que não dava aulas, mas que o avô dava. Entramos em contato com ele, combinamos dias e horas e comecei as aulas. É um processo demorado como qualquer outro, exigia muita prática e paciência - pois era/sou muito ansiosa. Assim, mesmo não tendo nenhum conhecimento do instrumento, queria 'de cara' tocar uma música. Mas soube administrar bem minha pressa e, apesar de ser 'iniciante' nesse vasto universo musical, depois de muita insistência e incentivo da minha tia, aprendi a tocar até hoje, graças ao meu querido professor, super atencioso e paciente, Samuel, com 67 anos e já vacinado contra o Covid!!!!!

De alguma forma, esse tipo de arte me atingiu através de redes educativas, me permitindo criar outras. Aos poucos, de infância a infância, fui percebendo que a arte é essa potência de atingir e sensibilizar o outro gerando movimentos, vibrações, criando memórias de infâncias que a cada momento ressurgem em nossas vidas.

\section{Memória-narrativas de uma professora de Artes Visuais}

Desde a primeira infância, me recordo da Arte como um instrumento de diversão, distração, criação e sobrevivência. As músicas, os sons, os movimentos da dança e as imagens, qualquer imagem - desenho, pintura, fotografia, adesivos, cartazes, papéis de carta, gibis, propagandas - sempre me fascinaram. Lápis de cor, hidrocores, tintas e canetas coloridas era o que eu gostava de ganhar e colecionar. Por vezes, me bastava somente ficar admirando e contemplando aqueles objetos como se fossem, em si, verdadeiras obras de arte. Com eles, eu ficava horas criando e ampliando pequenos desenhos para uma folha de cartolina para os trabalhos de escola com, apenas, 6, 7 anos de idade. Aliás, quando se tratava de utilizar qualquer forma ou imagem em trabalhos escolares eu sempre era requisitada.

Junto com o desenho, que me acompanha desde sempre, a dança fez parte de um pequeno período de minha infância, mas deixou marcas que ainda hoje lembro com saudade e afeto. Os movimentos leves e graciosos de uma professora de balé clássico me emocionaram de tal forma que escolhi fazer parte daquele universo mágico e encantador. Com muita dificuldade, mas com muita alegria, ganhei as roupas, as sapatilhas, os adereços de cabelo e a matrícula naquela escolinha de dança. Ali, me deparei com um universo que não era o meu, mas que aconchegou de tal modo que dali eu não queria sair. As músicas instrumentais, com melodia calma, se misturam com os movimentos leves e me fazem sonhar. Eu imaginava um futuro lindo na dança, com apresentações em teatros renomados, tanto dentro quanto fora do país. Desejava ser a melhor bailarina da minha 
geração e que, com muito estudo e dedicação, viveria de/para a Arte. Por questões financeiras, o sonho teve que ser interrompido.

O balé clássico ficou para trás, mas o corpo pedia movimentos e eu o atendia na sala de casa, entre amigas, em algumas festas e na escola. O desenho nunca me abandonou. Nem eu a ele. Ele me acalentava em dias cinzentos e em dias coloridos. Desencadeia um turbilhão de ideias que se espalhava pela casa, em cadernos, em livros e no chão. As bonecas de papel ganharam roupinhas recortadas também com papéis coloridos. Os objetos - qualquer objeto que estivesse ao alcance dos olhos - viravam um motivo a ser desenhado. Tudo virava Arte pelas minhas mãos. Cores, linhas e texturas se transformavam em criações, alegorias e diversão cotidianas.

Mas esse mundo de fantasias que habitou em minha infância e adolescência desde sempre virou profissão. Por acaso talvez - hoje acredito que não existiu esse tal acaso. Por alguns anos, acreditei que deveria seguir por outros caminhos. Mas a Arte novamente me capturou e mostrou a realidade: de que não poderia viver sem ela. Tudo o que tinha vivido, sentido, ouvido e pensado até então tinha me formado e proporcionado inúmeras experiências estéticas que também auxiliam na formação de outras pessoas.

Com essas redes vieram outras vivências: a fotografia, a aquarela, a dança de salão, a contação de história e inúmeras experimentações e criações em arte educação. Todos esses 'espaçostempos' de criação de 'práticasteorias' que se articularam e ainda se articulam permanentemente ao longo de minha vida, "embora com intensidades e sentidos diversos" (ALVES, 2019). Tudo isso me marcou em criança, como adolescente e ainda me marcam como professora de Artes, no contato com tantas crianças e adolescentes, que me permitem ver nelas e vivenciar com elas outras infâncias.

Diversos artefatos culturais que resgatam uma memória afetiva dos meus anos de ensino básico, que prendiam enormemente a minha atenção e despertavam o meu interesse pelos conteúdos abordados, agora são utilizados como artefatos curriculares na 'aprendizagemensino' das Artes Visuais na rede pública que leciono. Imagens de obras de arte, animações e curtas-metragens são imprescindíveis para uma criação artística, ética estética, significativa e carregada de múltiplas afecções.

\section{As 'cineconversas' e as relações com a sétima arte}

No grupo de pesquisa em que atuamos, entendemos os cotidianos como 'espaçostempos' de criações, conversações, dinâmicas e encontros diversos com as artes, 
em uma postura escolhida trazendo a Ética, a Estética e a Política, nas ações produzidas. Nesses encontros, entramos em contato com 'fazeressaberes' e narrativas de todos os 'praticantespensantes' das pesquisas, que nos trazem, com frequência, memórias de nossas tantas infâncias que, lembradas, nos encaminham para ações curriculares com as artes. Esses agenciamentos éticos, estéticos e políticos nos conduzem a buscar compreender as infâncias - e adolescências - de hoje através de nossas tantas infâncias que ali se articulam, produzindo belezas, ações éticas e soluções políticas para as tantas questões curriculares que enfrentamos.

Nas 'cineconversas' - entendidas como o lócus centro dos processos de pesquisa múltiplos e diversos filmes são trazidos para produzir pensamentos sobre educação e sobre os cotidianos nos quais estamos inseridos. Ao 'verouvirsentirpensar' um filme entendemos que não conseguimos dicotomizar os sentidos, memórias e as afetações que ele produz e que seu uso é um fio condutor importante para ressignificações e criações outras nos cotidianos.

As cineconversas, como dispositivo de sensibilização e reflexão, se dão pela afetação ao assistir a um filme e em seguida, conversar acerca das afetações provocadas por essa narrativa que envolve os diferentes elementos da linguagem cinematográfica (imagem composta pela luz; enquadramentos; movimentos de câmera; relação 'espaçotempo' como ritmo e ordenação na montagem; o som com sua ambiência sonora, trilhas e músicas; e por fim, a abordagem temática, com o argumento e roteiro) e ainda, a forma como essa narrativa é percebida por cada pessoa, de acordo com sua particular história de vida (MACHADO; MORAIS; TOJA, 2020, p. 96).

Não é necessário que sejamos bons entendedores de cinema, pois a metodologia da nossa pesquisa valoriza as conversas e o processo dialógico com os filmes como provocadores de sentimentos e sensações que, muitas vezes, encontram-se escondidos ou adormecidos pelas distrações ou tensões diárias. O aparecimento frequente, nas 'cineconversas', das memórias de infâncias em contato com o cinema nos traz a compreensão dessas diversas infâncias tão diferentes produzidas no país em que vivemos e no Mundo.

\section{O contato precoce com os sons}

Em nosso grupo, nas pesquisas que realizamos, para além das imagens visuais dos filmes, temos nos dedicado também a compor nossos conhecimentos com os sons que os filmes nos trazem. Assim, os filmes 'vistosouvidossentidospensados', nos respondem a necessidade de conversar com nossos mundos imagético-sonoros em que vivemos e 
buscar compreender o que nossas memórias de nossas tantas infâncias nos trazem em múltiplas narrativas que surgem nas 'cineconversas'. O som está em nossas vidas desde a nossa formação como feto. Está comprovado, em estudos diversos, que os fetos humanos são capazes de memorizar estímulos auditivos do mundo externo até o último trimestre da gravidez.

Acrescendo que a fala é um componente da linguagem que funciona racional e logicamente para uma efetiva compreensão, tanto como atua emocionalmente em nossas vidas; tanto que detém uma característica comum e perceptível entre seus falantes, a prosódia, fenômeno linguístico referente às composições gestuais e aos aspectos sonoros ligados à entonação do falar.

Assim, dizemos, com as mesmas palavras, "Amanhã tem festa" e "Amanhã tem festa?". Graficamente, o que muda é apenas a pontuação, mas linguisticamente, essa diferença ocorre na entonação das frases ditas, ou seja, nesse exemplo, a entonação da penúltima sílaba distingue uma pergunta de uma afirmação. Ao mesmo tempo, essas mesmas frases podem ser ditas com emoções diferentes, pelo interesse que temos ou não na festa anunciada ou mesmo quem foi o responsável por produzir o questionamento. Nela, não temos interesse nenhum ou temos algum interesse particular, que nos faz diferentemente pronunciá-la ou ouvi-la.

Em certo sentido, o choro faz parte da fala. Os neurolinguistas nem sempre pensaram assim, pois acreditavam que o choro dos bebês dependia inteiramente do ciclo respiratório. O choro era concebido, portanto, como um comportamento meio automático e, à parte seu óbvio significado de desprazer e contrariedade, desprovido de maior semelhança com a fala, cuja articulação é bastante (mas não por completo) independente da respiração. Conclusões diferentes derivaram de um interessante trabalho em que o choro é moldado ritmicamente pela língua nativa, isto é, aprendizado vocal baseado em inclinações biológicas.

O estudo foi realizado por pesquisadoras francesas e alemãs em que gravaram o choro de 60 bebês recém-nascidos: 30 filhos de famílias monolíngue alemã e 30 filhos de famílias monolíngue francesa. De cada choro foram analisadas as propriedades melódicas, isto é, relativas à passagem dos tons produzidos e às suas características de intensidade. Os resultados do trabalho mostraram que os bebês franceses choram de forma parecida com a fala dos franceses adultos. Em contraste, os bebês alemães choram "em alemão".

A conclusão mais importante do trabalho das pesquisadoras franco-alemãs não se refere à nacionalidade do choro ou da fala, mas ao fato de que são característicos da língua nativa. De fato, existem evidências de que a entonação da fala dos adultos, especialmente 
a fala da mãe - a pessoa que passa mais tempo com o feto - ultrapassa a parede abdominal e é percebida de algum modo pelo feto dentro do útero. Não acontece com a fonética (a fala) mas acontece com a prosódia (a entonação). Tudo isso indica que informações auditivas podem ser detectadas dentro do útero e que o contato com os sons é anterior à existência exterior humana.

\section{Pedagogia dos sons}

Schafer (1991), compositor, educador e pesquisador canadense nos traz, em 'O ouvido pensante', ideias acerca dos sons do mundo, enfatizando a criação e modos de percepção sonora. Os sons e suas relações com as outras artes e com a vida, não é manifestado necessariamente obedecendo apenas um padrão - uma nota, melodia, ritmo - eles existem e as notas, melodia, ritmo coexistem acrescentando-os com a possibilidade de torná-los um tipo de arte. Schafer exemplifica isso em uma atividade para estimular a criação que ele denomina de "o compositor na sala de aula".

Tudo começa quando um cantor (estudante) afirma que não sabem nenhuma canção de horror e o educador propõe uma situação - assustadora - em que eles sentissem medo e acuados e pergunta a reação que teriam e a resposta de um dos alunos foi: "eu gritaria" e então, os incentivou a desenvolver. Ainda incrédulo o estudante pergunta: "Quando você tocar o acorde quer que a gente grite?" E Schafer, responde: "Com toda força e pulmões! Pronto? Vamos lá!" E assim se forma uma sequência de gritos gerando um som estrondoso e sem deixar ninguém em dúvida se foi agradável ou não ao ouvido. Porém, como som ele serviu perfeitamente a proposta inicial sendo considerado por ele um som musical porque era a trilha sonora que foi pedida por ele. Além disso, fala sobre a "intenção" que determina se o som produzido é para ser intencionalmente ouvido ou não.

Acerca disso, percebemos que os sons são subjetivos e carregam múltiplas funções e finalidades. Por analogia, trago uma narrativa de infância vivenciada na escola por uma de nós: foi proposto um exercício de assobio. A professora fazia e nós tínhamos que reproduzir e assim foi feito. Várias tentativas de sopros lançados ao ar, não chegavam a ser um assobio, de fato, mas a intenção do som e a textura correspondia ao que foi pedido. Por extensão, é assim que os compositores trabalham, reagem a uma sugestão e transformam em música original. Precisamos incluir, aqui também, as emoções trazidas nas experiências de crianças - que aparecem em risos - e a experiência magnífica das emoções de músicos que nos trazem sua arte. 
Schafer (1991) descreve o ruído como qualquer som que interfere ou destrói o que queremos ouvir, qualquer som indesejado. Para o autor, qualquer coisa que se movimenta, em qualquer canto do mundo, que oscila mais de dezesseis vezes por segundo e que "vibra o $\mathrm{ar}^{\prime \prime}$ pode ser entendida e ouvida como som.

O mundo está cheio de som. Ouça. Abertamente atento a tudo que estiver vibrando, ouça. Sente-se em silêncio por um momento e receba os sons. Muitas vezes descobrimos que desenvolvemos uma consciência aguda de um sentido receptor eliminando os outros (SCHAFER, 1991).

Mesmo quando nos deitamos e colocamos um dos braços próximo a nossa cabeça, ouvimos o som de nosso sangue circulando, antes de adormecer. O que primeiro nos acorda é sempre um som. Com os sons conhecemos o mundo e pensamos. Nossos trabalhos nos levaram a entender, no entanto que pensamos com todos os nossos sentidos: imagens, sons, sabores, cheiros, tatos...nos levam, todos, a aprender, reconhecer e pensar. Criam narrativas, acumulam memórias, organizam álbuns de fotografias, criam as comidas de família, forjam hábitos alimentares...nos fazem humanos (ALVES; CALDAS; CHAGAS; MENDONÇA, 2020, p. 237).

Nesse processo de 'cineconversas', vimos o filme alemão "Nunca deixe de lembrar" (2018) de Florian Henckel von Donnersmarck, baseado na vida do pintor alemão Gehard Richter entre 1937 e 1966. Logo no seu início, conseguimos perceber essa articulação de sons, imagens, narrativas, graças ao que é trazido no filme na relação do menino - que depois se transformaria no pintor - visitando com sua tia Elisabeth a exposição intitulada "Arte degenerada"5. Após a vista, no caminho de casa, já no fim da tarde, Elisabeth se despede do motorista, desce do ônibus e caminha, com um casaco apoiado nos braços, de mãos dadas com Kurt.

Na sequência, mostra o mesmo ônibus que ela havia descido dando meia volta, indo estacionar junto com outros ônibus e Elizabeth indo ao seu encontro. A criança pergunta se ela esqueceu alguma coisa, mas sua tia apenas olha para ele com um leve sorriso e continua seu caminhar. Ao parar, olhando para os ônibus, une as mãos em sinal de pedido, abre um largo sorriso e aguarda. A cena para e o som abafa. Os motoristas começam a contagem 1,2 e 3 . As buzinas de todos os ônibus então ecoam. A tia de Kurt abre os braços, a música e a câmera gira em $360^{\circ}$ mostrando o som das buzinas atravessando-a.

\footnotetext{
${ }^{5} \mathrm{~A}$ arte naquele momento considerada 'degenerada' não deixou de ser exposta pelos nazistas. Os quadros julgados como proibidos eram apresentados para serem criticados e colocados em confronto com a "arte verdadeira", aquela imaginada pelos nazistas, em nome da 'verdadeira' Alemanha.
} 
Após a êxtase da orquestra de buzinas, Elisabeth fala para Kurt: "pinte um quadro que te faça sentir assim. É isso que eles estão tentando fazer - os artistas degenerados".

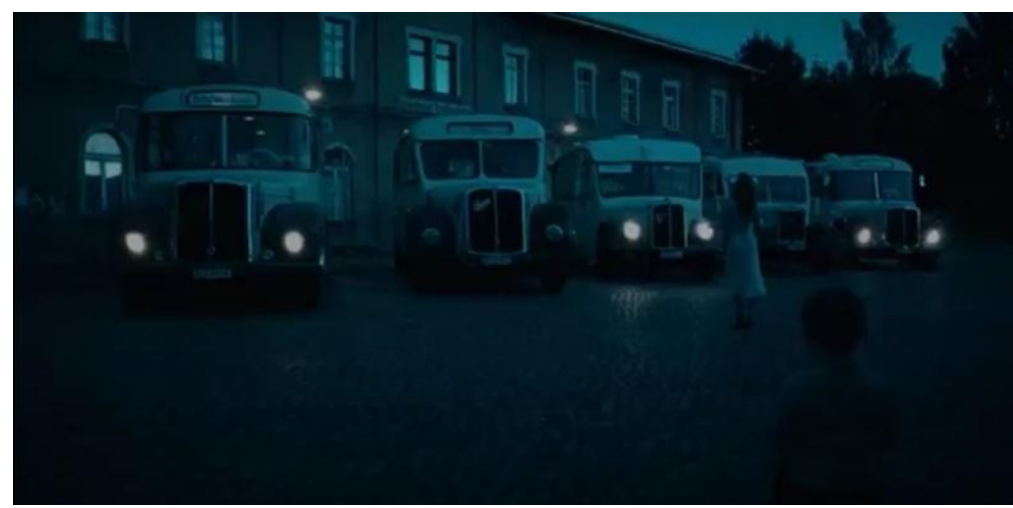

Figura 1: os ônibus

Fonte: Filme "Nunca deixe de lembrar" (2018).

Sobre essa simbiose entre imagens e sons mostrada no filme, Tesser (2009) comenta que o visual e o sonoro são componentes autônomos de uma mesma obra e em meio a essa relação o som vai se libertar como linguagem, sem que precise se estabelecer como ilustração da imagem, assim como a imagem também vai se libertar não precisando mais ser informativa. Podemos perceber então que os filme(s) visto(s) permite(m) 'verouvirsentirpensar', incluindo questões que passam pelas tantas redes educativas que formamos e nas quais nos formamos (ALVES; CALDAS; CHAGAS; MENDONÇA, 2020).

O visível e o sonoro estão em estreita conexão com os movimentos do mundo, são interdependentes e se fazem com eles. 0 deslocamento descortina toda uma sensibilidade e mobiliza a educação da atenção. O tato e o ouvido são sentidos que nos conectam de modo sensível ao visível, criando políticas, éticas e estéticas diversas e complexas. Eles podem ser compreendidos como uma antropofagia, porque os traços e rastros do que se 'vêouvecheiratoca' - se sente, para dizer em uma palavra - são transformados em ser e nos fazem pensar (ALVES; CALDAS; CHAGAS; MENDONÇA, 2020, p. 231).

Esse filme-referência trata, exatamente, das relações de memórias do menino para solucionar e criar com elas as suas obras. Sua obra vem, no filme, criada com essas tantas vivências de criança e sua capacidade de pensar e criar com elas, no movimento de suas memórias.

Pensando nessa continuidade de cenas sublinhada acima, uma de nós, remexendo suas lembranças, divaga entre os tantos ruídos de sua infância. "Minha ida à escola, todos os dias, era um momento esperado. Já aos sete anos, eu pegava a bicicleta e, de garupa com minha irmã, ia observando os ruídos das conversas de portão dos vizinhos, dos carros 
e motos que por nós passavam. Recordo das salas de aula da minha escola, todas com meia parede branca e portas azuis, uma ao lado da outra dando para um corredor.

Os ecos e os ruídos eram inevitáveis e aguçaram ainda mais a curiosidade pelo que estava acontecendo porta afora. Os burburinhos do outro lado chamavam a atenção para o recreio. Minha sala era a última desse longo corredor. Todos que eram liberados para o recreio passavam pela minha sala. E eu, curiosamente, esperava ansiosa minha vez. Mas para mim, esses ruídos em forma de risos, gritos, passos, crianças correndo ou apenas murmúrios - já que o inspetor tentava controlar os barulhos no corredor - significam hoje algumas alegrias despertadas nos cotidianos, com as memórias que surgem com elas. Lembro, que a turma, apressava a professora. Está na hora professora! É nossa hora! E ela pacientemente, entre sorrisos, falava que estava terminando".

Assim, trazidas por memórias coletivas ou individuais, as imagens e os sons estão presentes em narrativas nos sucessivos projetos, criando 'conhecimentossignificações', sendo incorporadas aos modos de 'sentirpensar' dos processos que realizamos (ALVES; CALDAS; CHAGAS; MENDONÇA, 2020, p. 232). Todas as nossas crianças, as que fomos e aquelas com que nos relacionamos hoje, estão presentes nesses processos todos.

\section{Conclusão}

Em tempos pandêmicos que redigimos esse texto, entendemos que manter as alegrias das crianças que temos em nós é um movimento necessário. Schafer (1991) narra que para as crianças arte é vida e vida é arte. A experiência, para elas, é um fluido "caleidoscópico" - colorida que através do reflexo das suas vivências se movimentam em arranjos diversos e "sinestésico" pois percebem diferentes sensações em suas ações: visão, audição, olfato, paladar e tato. Schafer comenta, ainda, que se observamos crianças brincando nos seria impossível delimitar suas atividades em categorias.

\section{Referências}

ALVES, N.; CALDAS, A. N.; BRANDÃO, R. Formação de professores com filmes: os clichês como formadores de docentes e indicadores dos múltiplos caminhos da centralização curricular. Revista e-Curriculum. São Paulo: Programa de Pós-graduação Educação: Currículo - PUC/SP, v.13, n.04, 2015.

ALVES, N.; CALDAS, A. N.; CHAGAS, C. C.; MENDONÇA, R. Imagens, sons e narrativas: criar conhecimentos e formar docentes. Revista Educação em foco. Juiz de Fora/MG, v. 25, n. 2, jan/abr 2020. 
ALVES, N. Sobre as redes educativas que formamos e que nos formam. In ALVES, N. Práticas pedagógicas em imagens e narrativas - memórias de processos didáticos e curriculares para pensar as escolas hoje. São Paulo: Cortez, 2019, p. 115-134.

GONÇALVES, C. B. V.; DELBONI, T. M. Z. G. F. As dobras produzidas com as fabuloinvenções das crianças nas aulas-acontecimentos. Revista Teias - Seção Temática Docência, currículo, didática, aula: fantástico arquivo político da diferença. V. 21 , n. 63 , out./dez. 2020, p. 340-354.

\section{LASZLO, E. A Plenitude do cosmos: a revolução akashica na ciência e na} consciência humana. Rio de Janeiro: Cultrix, 2018.

LENT, Roberto. Seu bebê chora em que língua. Ciência Hoje. Rio de Janeiro, 2009. Disponível em: <https://cienciahoje.org.br/coluna/seu-bebe-chora-em-que-lingua/>.

MACHADO, M. F.; MORAIS, M.; TOJA, N. Cineconversas' - criando currículos com filmes de migração. Revista de la Escuela de Ciencias de la Educación. A. 16, V. 1, n. 15, 2020.

MENDONÇA, R. H.; Santos, J. R.; TOJA, N.; MORAIS, M. "Cineconversas" e fabulações curriculantes: o uso de filmes e a potência das conversas como metodologia de pesquisa em educação. Revista e-Curriculum. V. 18 n.4, 2020.

RANCIÈRE, J. A partilha do sensível: estética e política. São Paulo: EXO experimental org.; Ed. 34, 2005.

SCHAFER, R. M. O ouvido pensante. São Paulo: EdUNESP, 1991.

SILVA BRANDÃO, R.; MENDONÇA, R. H.; PAPINI, R. Memórias de professoras: tecendo 'cineconversas' com o incrível exército de Brancaleone. Revista Brasileira de Pesquisa (Auto)biográfica, v. 5, n. 16, 2020.

TESSER, P. Música e imagem. In: FURTADO, B. (Org.). Imagem Contemporânea cinema, tv, documentários, fotografia, videoarte, games... Volume II. São Paulo, Hedra, 2009.

\section{FILME}

NUNCA DEIXE DE LEMBRAR. Direção: Florian Henckel von Donnersmarck. Colorido, 188 $\min , 2018$.

\footnotetext{
' Professora titular na Faculdade de Educação/UERJ e Faculdade de Educação/UFF (aposentada em ambas). Atualmente, é Pesquisadora emérita da FAPERJ, com exercício na UERJ, no Programa de Pós-graduação em Educação (campus Maracanã) e no PPGEProcessos Formativos e Desigualdades Sociais (campus S. Gonçalo). Ex-presidente da ANPEd (Associação Nacional de Pós-graduação e Pesquisa em Educação), da ANFOPE (Associação Nacional pela Formação dos Profissionais da Educação), da ABdC (Associação Brasileira de Currículo) e da ASDUERJ (Associação dos Docentes da UERJ). Organizadora de livros, séries e coleções, com artigos publicados no Brasil e no exterior. Fundadora, em 2001, e coordenadora, até 2014, do Laboratório Educação e Imagem/ProPEd/UERJ (www.lab-eduimagem.pro.br), no qual continua atuando. Trabalha em pesquisas com os cotidianos, articulando currículos, redes educativas, imagens, sons e formação de docentes.
} 
ii Graduanda no curso de Letras - Inglês/Literaturas e integrante com IC - bolsa/CNPq no GrPesc "Currículos cotidianos: redes educativas, imagens e sons.

iii Doutoranda em Educação pelo Programa de Pós-Graduação em Educação - Processos Formativos e Desigualdades Sociais (PPGedu/FFP) da Universidade do Estado do Rio de Janeiro - UERJ. Mestre em Educação pelo Programa de Pós Graduação em Educação, Contextos Contemporâneos e Demandas Populares (PGEduc/UFRRJ) 2013. Graduada em Pedagogia Plena pelo Instituto Multidisciplinar da Universidade Federal Rural do Rio de Janeiro - IM/UFRRJ (2010). Integrante do Laboratório Educação e Imagem/ProPEd/UERJ e do GrPesq Currículos cotidianos: redes educativas, imagens e sons e ambos coordenado pela Prof. Dra. Nilda Alves. Atualmente é professora substituta nos Anos Iniciais do Ensino Fundamental I do Colégio Pedro II-CP2.

iv Mestranda em Educação - ProPED / UERJ (2021), na linha de pesquisa "Cotidianos, Redes Educativas e Processos Culturais". Integrante do Grupo de Pesquisa "Currículos Cotidianos: redes educativas, imagens e sons", coordenado pela Profa. Nilda Alves. Especialista em Planejamento, Implementação e Gestão da EaD pela UFF (2016) e em Arte, Educação e Tecnologias Contemporâneas pela UnB (2012). Licenciada em Educação Artística, com habilitação em História da Arte, pela UERJ (2004). Atualmente é professora de Artes Visuais da Secretaria Municipal de Educação do Rio de Janeiro.

Como citar esse artigo:

ALVES, Nilda Guimarães; LIMA, Júlia da Silva; CONCEIÇÃO, Rafaela Rodrigues; GREGORIO, Talita Malheiros. SÓ AS ARTES NOS SALVAM!!!!! - as tantas crianças que há em nós -. Revista Digital do LAV, Santa Maria: UFSM, v. 14, n. 2, p. 158-172, mai./ago. 2021. 